\title{
Trans-dioxo Manganese(V) Porphyrins
}

\author{
Ning Jin, Mohammed Ibrahim $§$, Thomas G. Spiro ${ }^{*}$, , and John T. Groves* \\ Department of Chemistry, Princeton University, Princeton, New Jersey 08544
}

Transition metal oxo-species have been the focus of extensive studies because of their relevance to the redox biochemistry of dioxygen as well as myriads of oxidative catalytic processes. High valent oxo-manganese complexes have been described for porphyrin, ${ }^{1}$ salen, ${ }^{2}$ corrole,${ }^{3}$ corrolazine, ${ }^{4}$ and non-heme systems. ${ }^{5}$ The $\mathrm{O}=\mathrm{MnV}^{\mathrm{V}}$ moiety has been suggested in the photosynthetic water oxidation process, ${ }^{6}$ and a bridged $\mathrm{Mn}^{\mathrm{V}}$ porphyrin dimer has recently been demonstrated to oxidize water into dioxygen. ${ }^{7}$

We have previously described low-spin $\mathrm{d}^{2}$ oxomanganese(V) porphyrin complexes that display an extraordinary range of reactivity toward oxo-transfer as a function of prototropic equilibria involving the axial ligand. ${ }^{8}$ A prediction of that work was that oxo-aqua and oxo-hydroxomanganese $(\mathrm{V})$ intermediates are reactive oxidants while the stable species observed at high $\mathrm{pH}$ are trans-dioxo complexes. Here we provide the first definitive spectroscopic evidence for trans-dioxomanganese $(\mathrm{V})$ porphyrins $\left[\mathrm{O}=\mathrm{Mn}^{\mathrm{V}}=\mathrm{O}\right]$. Further, we show that protonation of these species affords the reactive intermediates usually associated with these catalytic systems (Scheme 1).

Oxidation of Mn ${ }^{\mathrm{III}}-5,10,15,20$-tetramesitylporphyrin (Mn ${ }^{\mathrm{III}} \mathrm{TMP}$ ) with 1.2 equiv of $\mathrm{H}_{2} \mathrm{O}_{2}$ in $\mathrm{CD}_{3} \mathrm{CN} / \mathrm{CD}_{2} \mathrm{Cl}_{2}$ containing excess tetrabutylammonium hydroxide (TBAH), in a variation of the conditions reported previously by us ${ }^{8 \mathrm{~d}}$ and recently by Nam et al., ${ }^{9}$ yielded a solution with sharp, well-resolved ${ }^{1} \mathrm{H}$ NMR resonances typical of a diamagnetic oxo $\mathrm{Mn}^{\mathrm{V}}$ complex (Figure S1). Intriguingly, the ortho-methyl resonance of the mesityl substituent appeared as a sharp singlet at $\delta 1.87$, in contrast to the $t w o$, well-resolved singlets observed for the isoelectronic oxoCr ${ }^{\mathrm{IV}} \mathrm{TMP}$ and nitridoMn ${ }^{\mathrm{V}} \mathrm{TMP} .{ }^{10}$ The equivalence of the ortho-methyl protons in $\mathrm{Mn}^{\mathrm{V}} \mathrm{TMP}$ could result from a compound of $C_{4 v}$ symmetry with rapid axial ligand interchange, such as by oxo-hydroxo tautomerism. ${ }^{11}$ Alternatively, a $D_{4 h}$ symmetric compound with identical axial ligands, such as a trans-dioxo arrangement $\left[\mathrm{O}=\mathrm{Mn}^{\mathrm{V}}=\mathrm{O}\right]$, would also display these features. Significantly, the ortho-methyl signal remained sharp with no evidence of exchange broadening even at $-20^{\circ} \mathrm{C}$. This observation suggests either that oxo-hydroxo tautomerism is unusually fast, even at this low temperature in an aprotic medium, or that the trans-dioxo formulation is the correct one.

Confirmation of the $D_{4 h}$ symmetry of the oxidized $\mathrm{Mn}^{\mathrm{V}}$ porphyrin species and assignment of the structure as a trans-dioxo $\mathrm{Mn}^{\mathrm{V}}$ complex were made on the basis of the Raman and IR spectra. Figure 1a shows Raman spectra of $\mathrm{Mn}^{\mathrm{V}}$ tetrapentafluorophenylporphyrin (Mn ${ }^{\mathrm{V}}$ TPFPP) generated by oxidation of $\mathrm{Mn}^{\mathrm{III}} \mathrm{TPFPP}$ with $\mathrm{H}_{2} \mathrm{O}_{2}$. Oxidation with $\mathrm{H}_{2}{ }^{18} \mathrm{O}_{2}$ in $\mathrm{H}_{2}{ }^{18} \mathrm{O}$ caused the band at $743 \mathrm{~cm}^{-1}$ to shift to $699 \mathrm{~cm}^{-1}$. This isotopic shift $\left(44 \mathrm{~cm}^{-1}\right)$ is considerably larger than expected for a simple, terminal $\mathrm{Mn}=\mathrm{O}$ stretch $\left(33 \mathrm{~cm}^{-1}\right)$ but is close to the calculated value for a linear triatomic model, ${ }^{18} \mathrm{O}=\mathrm{Mn}={ }^{18} \mathrm{O}\left(42 \mathrm{~cm}^{-1}\right)$.

jtgroves@ princeton.edu.

\$Present address: Department of Chemistry, University of Washington, Seattle, Washington 98195.

Supporting Information Available: Experimental details, NMR Raman, and IR spectra. This material is available free of charge via the Internet at http://pubs.acs.org. 
Oxo-hydroxo tautomerism was introduced by Meunier to explain the pattern of ${ }^{18} \mathrm{O}$-exchange into oxidized substrates mediated by water-soluble manganese porphyrins. ${ }^{11}$ We utilized this concept to generate half-labeled dioxo- $\mathrm{Mn}^{\mathrm{V}}$ porphyrins. Raman spectra for $\mathrm{Mn}^{\mathrm{V}} \mathrm{TPFPP}$ prepared using either $\mathrm{H}_{2}{ }^{16} \mathrm{O}_{2}$ in $\mathrm{H}_{2}{ }^{18} \mathrm{O}$ or $\mathrm{H}_{2}{ }^{18} \mathrm{O}_{2}$ in $\mathrm{H}_{2}{ }^{16} \mathrm{O}$ showed identical features (Figure 1a): the $743 \mathrm{~cm}^{-1}$ band shifted to $717 \mathrm{~cm}^{-1}$, in good agreement with the $22 \mathrm{~cm}^{-1}$ shift predicted for ${ }^{16} \mathrm{O}=\mathrm{Mn}={ }^{18} \mathrm{O}$ The $717 \mathrm{~cm}^{-1}$ band retained its intensity during the RR experiments $(\sim 10$ $\mathrm{min}$ ), indicating that oxygen exchange with bulk water is very slow. Moreover, the $v_{\text {sym }}(\mathrm{O}=\mathrm{Mn}=\mathrm{O})$ band is very sharp, with a half width of only $9 \mathrm{~cm}^{-1}$ that was unaffected by $\mathrm{D}_{2} \mathrm{O}$. By contrast, $\left[\mathrm{O}=\mathrm{Mn}^{\mathrm{V}}(\mathrm{OH})-\mathrm{TDMImP}\right]^{3+} 12$ has $v_{\text {sym }}$ at $731 \mathrm{~cm}^{-1}$ and a half width of 50 $\mathrm{cm}^{-1}$ that sharpened to $25 \mathrm{~cm}^{-1}$ in $\mathrm{D}_{2} \mathrm{O}$ (Supporting Information, Figure S7). We have previously ascribed the broadening of $\mathrm{HO}-\mathrm{M}=\mathrm{O}$ Raman bands to a combination of $\mathrm{M}-\mathrm{OH}$ hydrogen bonding and oxo-hydroxo tautomerism, ${ }^{13}$ features that are absent in $[\mathrm{O}=\mathrm{M}=\mathrm{O}]$.

The symmetrical $\mathrm{O}=\mathrm{Mn}^{\mathrm{V}}=\mathrm{O}$ stretching frequencies for four other $\mathrm{Mn}^{\mathrm{V}}$ porphyrins were also assigned (Table 1). In each case we were able to prepare the respective half labeled and fully labeled dioxo complexes. The $v_{\text {sym }}(\mathrm{O}=\mathrm{Mn}=\mathrm{O})$ values $\left(741-744 \mathrm{~cm}^{-1}\right)$ are comparable to $v$ $\left(\mathrm{Mn}^{\mathrm{IV}}=\mathrm{O}\right)$ in oxoMn ${ }^{\mathrm{IV}}$ porphyrins such as $\mathrm{O}=\mathrm{Mn}^{\mathrm{IV}} \mathrm{TMP}\left(754 \mathrm{~cm}^{-1}\right),\left[\mathrm{O}=\mathrm{Mn}^{\mathrm{IV}}(\mathrm{OH}) \mathrm{TM}-4-\right.$ $\mathrm{PyP}^{3+}\left(711 \mathrm{~cm}^{-1}\right),{ }^{13 \mathrm{a}}$ or $\left[\mathrm{O}=\mathrm{Mn}^{\mathrm{IV}}(\mathrm{OH}) \mathrm{TDMImP}\right]^{3+}\left(731 \mathrm{~cm}^{-1}\right)$, but significantly lower than five-coordinate triple-bonded $\mathrm{O}=\mathrm{Mn}^{\mathrm{V}}$ corrolazine or tetraamido complexes $\left(970-981 \mathrm{~cm}^{-1}\right)$. 4,14 As can be seen, $v_{\text {sym }}$ is insensitive to the nature of the meso substituent. Similar observations have been made for structurally related dioxo $\mathrm{Ru}{ }^{\mathrm{VI}}$ porphyrins, ${ }^{15}$ while fivecoordinate $\mathrm{O}=\mathrm{Cr}^{\mathrm{IV}}$ porphyrins or $\mathrm{O}=\mathrm{Mn}^{\mathrm{V}}$ tetraamido complexes are more sensitive to ligand substituents. ${ }^{14,15}$

The IR spectrum of $\mathrm{Mn}_{\mathrm{V}} \mathrm{TPFPP}$ afforded strong confirmation of the Raman assignments (Figure 1b). The IR-active but Raman-inactive $v_{\text {asym }}$ for ${ }^{16} \mathrm{O}=\mathrm{Mn}={ }^{16} \mathrm{O}$ was found by bandfitting to be at $805 \mathrm{~cm}^{-1}$. For the half-labeled sample, a prominent new band appeared at 789 $\mathrm{cm}^{-1}$ and an adjacent porphyrin band at $802 \mathrm{~cm}^{-1}$ sharpened significantly (expected halflabeled shift is $15 \mathrm{~cm}^{-1}$ ). The fully labeled sample displayed a new band at $780 \mathrm{~cm}^{-1}$, also in good agreement with the calculated shift of $29 \mathrm{~cm}^{-1}$.

Taken together, the Raman, IR, and NMR data provide unequivocal evidence for a $D_{4 h^{-}}$ symmetric trans-dioxoMn ${ }^{\mathrm{V}}$ bonding arrangement in these compounds. Such dioxo complexes have been previously proposed by $\mathrm{Su}^{16}$ and us ${ }^{8 \mathrm{~b}, \mathrm{c}}$ for water-soluble oxoMn ${ }^{\mathrm{V}}$ porphyrins on the basis of the $\mathrm{pH}$-dependence of oxo-transfer rates, DFT calculations, and electrochemical studies.

It is instructive to compare the $\mathrm{Mn}-\mathrm{O}$ stretching frequencies observed here to those of terminal monooxo-manganese complexes. On the basis of $v_{\text {sym }}$ and $v_{\text {asym }}$, the oxo-manganese bond force constant $(F)$ and stretch-stretch constant $(k)$ for $\left[\mathrm{Mn}^{\mathrm{V}}(\mathrm{O})_{2} \mathrm{TPFPP}\right]^{-}$were determined to be 454 and $67.2 \mathrm{~N} / \mathrm{m}$, respectively. Application of Badger's rule ${ }^{17 \mathrm{a}}$ to the available data produces a very good correlation between $\mathrm{F}(\mathrm{Mn}-\mathrm{O})$ and the bond length, spanning five $\mathrm{Mn}$ oxidation states (Figure 2). Green has recently reported a similarly good correlation for oxoiron (IV) porphyrin complexes. ${ }^{17 \mathrm{~b}}$ As can be seen, the $\mathrm{O}=\mathrm{Mn}^{\mathrm{V}}=\mathrm{O}$ porphyrin appears on the fitted line in the middle of the known range, using the recently reported EXAFS bond length, ${ }^{9,18}$ consistent with two equivalent manganese-oxygen double bonds.

Dioxo-Mn ${ }^{\mathrm{TPFPP}}{ }^{-}$, as prepared, is unreactive toward olefins, as we have found for watersoluble $\mathrm{Mn}^{\mathrm{V}}$-porphyrins at high $\mathrm{pH} .{ }^{8 \mathrm{~b}}$ However, neutralization of the excess base with 1 equiv of trifluoroacetic acid caused an instantaneous reaction with added cyclooctene at $-70{ }^{\circ} \mathrm{C}$. Cyclooctene oxide was formed in $66 \pm 5 \%$ yield. Control reactions in the absence of acid yielded no epoxide. When $\left[\mathrm{Mn}^{\mathrm{V}}(\mathrm{O})_{2} \text { TPFPP }\right]^{-}$was half-labeled with $\mathrm{H}_{2}{ }^{18} \mathrm{O}_{2}$ (in excess 
$\mathrm{H}_{2}{ }^{16} \mathrm{O}$ ), the epoxide product contained $40 \pm 3 \%{ }^{18} \mathrm{O}$, showing that oxo exchange with bulk solvent is slow compared to the protonation-induced epoxidation reaction.

The low reactivity of dioxo- $\mathrm{Mn}^{\mathrm{V}}$ porphyrins can be readily understood to result from the net negative charge on the $\left[\mathrm{Por}-\mathrm{Mn}^{\mathrm{V}}(\mathrm{O})_{2}\right]^{-}$unit and, as with other manganates, the need to protonate an oxo-ligand to transfer the other oxygen to the substrate, as we have proposed..$^{8 \mathrm{c}}$ Charge is a powerful mediator of electrophilic reactivity. Monooxo $\mathrm{Mn}^{\mathrm{V}}$ corroles, corrolazines, and tetraamides are known to be poor oxygen atom donors because of the tri-or tetraanionic nature of the ligand. Under typically neutral catalytic conditions, dioxo- $\mathrm{Mn}^{\mathrm{V}}$ species would be in acid-base equilibrium with the oxo-hydroxo and oxo-aqua forms. $\mathrm{OxoMn}{ }^{\mathrm{V}}$ porphyrins bearing no axial ligand [Por- $\left.\mathrm{Mn}^{\mathrm{V}}=\mathrm{O}\right]^{+} 19$ or bearing weak-field ligands, such as hydroxo, are expected to be responsible for substrate oxygenation with high reactivity.

These $\mathrm{Mn}_{\mathrm{V}}$ porphryins appear to be the only trans-dioxomanganese compounds of any type to be spectroscopically characterized. Trans-dioxo metal complexes are typically found for low-spin $\mathrm{d}^{2}$ second or third row metals such as $\mathrm{Ru}^{\mathrm{VI}}$ and $\mathrm{Mo}^{\mathrm{IV}}$. It is apparent that a full understanding of the electronic structure and reactivity of high-valent manganese must include consideration of the transdioxo bonding mode, thus extending the known $\pi$-bonding arrangements found in first-row transition metals that were first discussed by Ballhausen and Gray. ${ }^{20}$

\section{Supplementary Material}

Refer to Web version on PubMed Central for supplementary material.

\section{Acknowledgments}

Support of this research by the National Science Foundation (Grant CHE 0616633) is gratefully acknowledged.

\section{References}

1. Meunier B, de Visser SP, Shaik S. Chem. Rev 2004;104:3947-3980. [PubMed: 15352783]

2. McGarrigle EM, Gilheany DG. Chem. Rev 2005;105:1563-1602. [PubMed: 15884784]

3. Gross Z, Gray HB. Adv. Synth. Catal 2004;346:165-170.

4. Kerber WD, Goldberg DP. J. Inorg. Biochem 2006;100:838-857. [PubMed: 16564091]

5. Parsell TH, Behan RK, Green MT, Hendrich MP, Borovik S. J. Am. Chem. Soc 2006;128:8728-8729. [PubMed: 16819856]

6. McEvoy JP, Brudvig GW. Chem. Rev 2006;106:4455-4483. [PubMed: 17091926]

7. Shimazaki Y, Nagano T, Takesue H, Ye BH, Tani F, Naruta Y. Angew. Chem., Int. Ed 2004;43:98100.

8. (a) Jin N, Groves JT. J. Am. Chem. Soc 1999;121:2923-2924. (b) Jin N, Bourassa JL, Tizio SC, Groves JT. Angew. Chem., Int. Ed 2000;39:3849-3851. (c) De Angelis F, Jin N, Car R, Groves JT. Inorg. Chem 2006;45:4268-4276. [PubMed: 16676990] (d) Groves JT, Watanabe Y, McMurry TJ. J. Am. Chem. Soc 1983;105:4489.

9. Song WJ, Seo MS, George SD, Ohta T, Song R, Kang MJ, Tosha T, Kitagawa T, Solomon EI, Nam W. J. Am. Chem. Soc 2007;129:1268-1277. [PubMed: 17263410]

10. (a) Groves JT, Kruper WJ, Haushalter RC, Butler WM. Inorg. Chem 1982;21:1363-1368. (b) Groves JT, Takahashi T. J. Am. Chem. Soc 1983;105:2073-2074.

11. Bernadou J, Fabiano AS, Robert A, Meunier B. J. Am. Chem. Soc 1994;116:9375-9376.

12. Lahaye D, Groves JT. J. Inorg. Biochem 2007;101:1786-1797. [PubMed: 17825916]

13. (a) Czernuszewicz RS, Su YO, Stern MK, Macor KA, Kim D, Groves JT, Spiro TG. J. Am. Chem. Soc 1988;110:4158-4165. (b) Su YO, Czernuszewicz RS, Miller LA, Spiro TG. J. Am. Chem. Soc 1988;110:4150-4157. 
14. Workman JM, Powell RD, Procyk AD, Collins TJ, Bocian DF. Inorg. Chem 1992;31:1548-1550.

15. Fujii H, Kurahashi T, Tosha T, Yoshimura T, Kitagawa T. J. Inorg. Biochem 2006;100:533-541. [PubMed: 16510186]

16. Chen FC, Cheng SH, Yu CH, Liu MH, Su YO. J. Electroanal. Chem 1999;474:52-59.

17. (a) Badger RM. J. Chem. Phys 1935;3:710-714. (b) Green MT. J. Am. Chem. Soc 2006;128:19021906. [PubMed: 16464091]

18. It is clear from the data presented herein that the $\mathrm{Mn}(\mathrm{V})$ complexes reported in ref ${ }^{9}$ are also anionic, $D_{4 h}$-symmetric dioxo species. We suspect that the broad RR bands reported there with smaller isotopic shifts $\left(34 \mathrm{~cm}^{-1}\right)$ are those of $\mathrm{O}=\mathrm{Mn}^{\mathrm{IV}}-\mathrm{OH}$ complexes derived from photoreduction (cf. ref 13 ).

19. Zhang R, Horner JH, Newcomb M. J. Am. Chem. Soc 2005;127:6573-6582. [PubMed: 15869278]

20. Ballhausen CJ, Gray HB. Inorg. Chem 1962;1:111-122. 


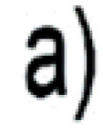

$$
v_{\text {sym }}=743 \mathrm{~cm}^{-1} \text { D) } \quad v_{\text {asym }}=805 \mathrm{~cm}^{-1}
$$

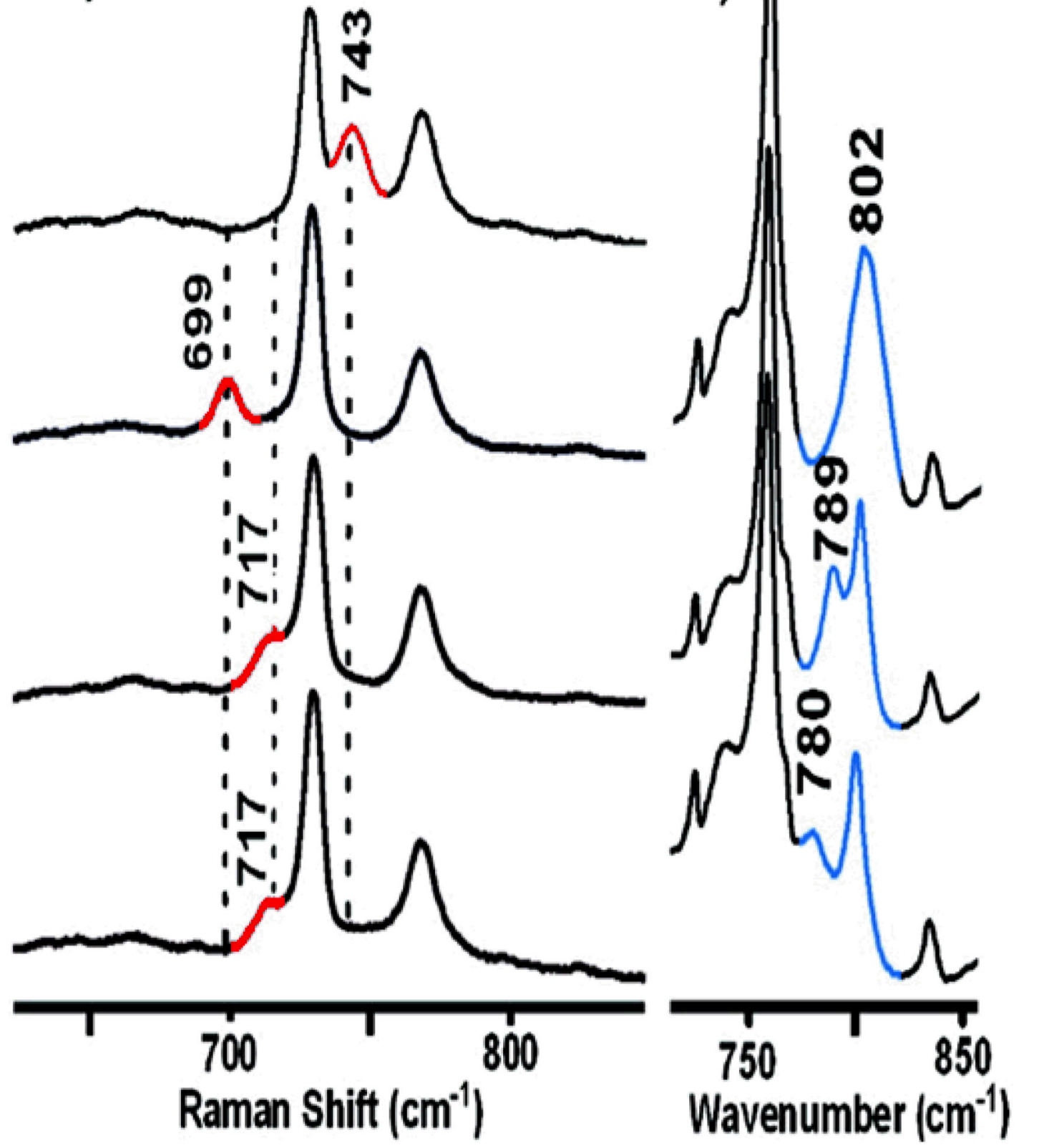

Figure 1.

(a) RR spectra of $\left[\mathrm{Mn}^{\mathrm{V}}(\mathrm{O})_{2} \mathrm{TPFPP}\right]^{-}$generated with (from top to bottom) 1.2 equiv $\mathrm{H}_{2} \mathrm{O}_{2}$ in $\mathrm{H}_{2} \mathrm{O}, \mathrm{H}_{2}{ }^{18} \mathrm{O}_{2}$ in $\mathrm{H}_{2}{ }^{18} \mathrm{O}, \mathrm{H}_{2}{ }^{16} \mathrm{O}_{2}$ in $\mathrm{H}_{2}{ }^{18} \mathrm{O}$, and $\mathrm{H}_{2}{ }^{18} \mathrm{O}_{2}$ in $\mathrm{H}_{2}{ }^{16} \mathrm{O}$, respectively, in a 9:1 ( $\mathrm{v}$ / v) $\mathrm{CH}_{3} \mathrm{CN} / \mathrm{H}_{2} \mathrm{O}$ containing $10 \mathrm{mM}$ TBAH. (b) IR spectra of solid $\left[\mathrm{Mn}^{\mathrm{V}}(\mathrm{O})_{2} \mathrm{TPFPP}^{-}\left[\mathrm{NR}_{4}\right]\right.$ + generated with (from top to bottom) $\mathrm{H}_{2} \mathrm{O}_{2}$ in $\mathrm{H}_{2} \mathrm{O}, \mathrm{H}_{2}{ }^{18} \mathrm{O}_{2}$ in $\mathrm{H}_{2}{ }^{16} \mathrm{O}$, and $\mathrm{H}_{2}{ }^{18} \mathrm{O}_{2}$ in $\mathrm{H}_{2}{ }^{18} \mathrm{O}$, respectively (see Supporting Information, Figures S3 and S8). 


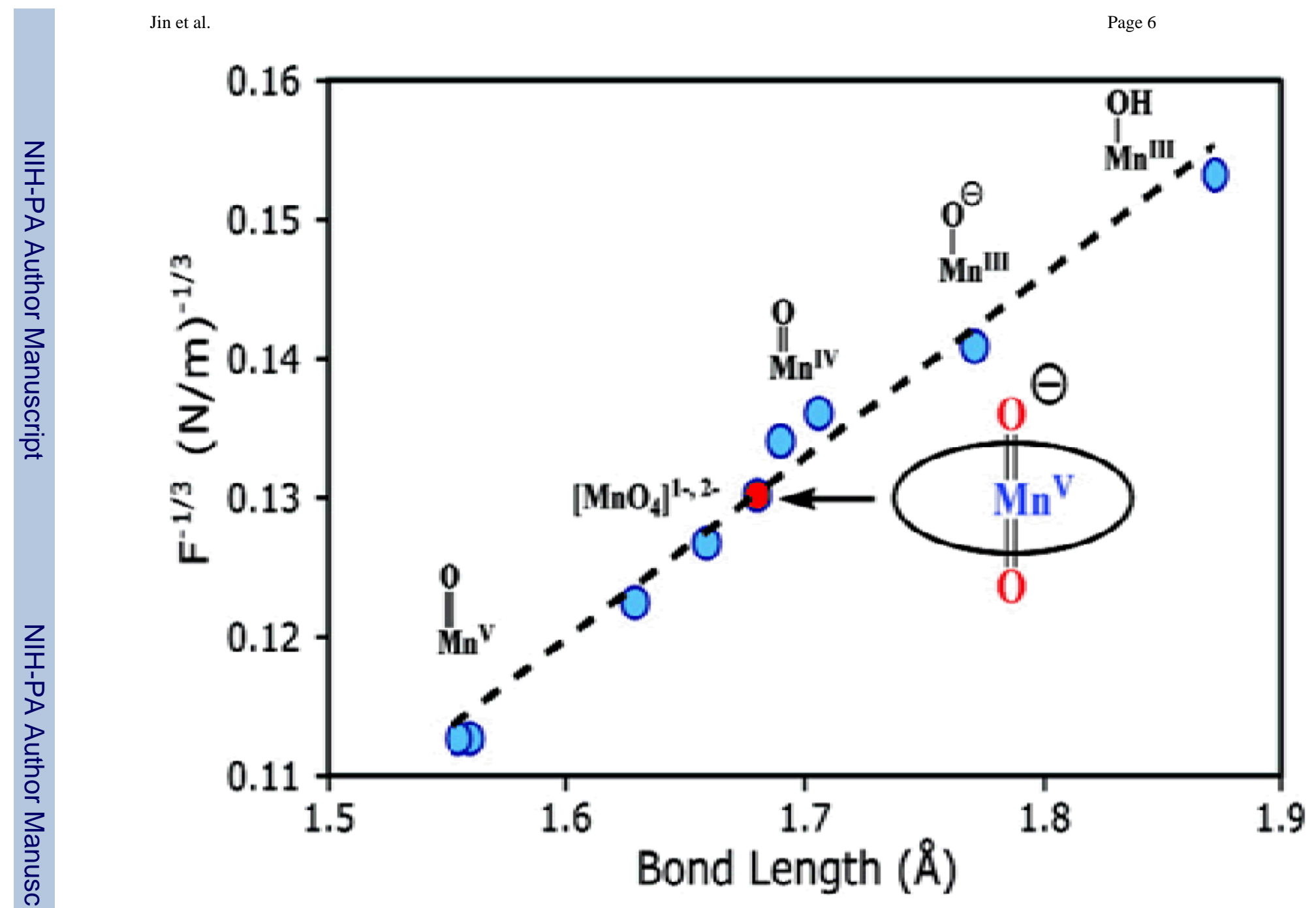

Figure 2.

MnO bond length vs $1 / \mathrm{F}_{\mathrm{Mn}-\mathrm{O}}{ }^{1 / 3}$ (see Supporting Information). 


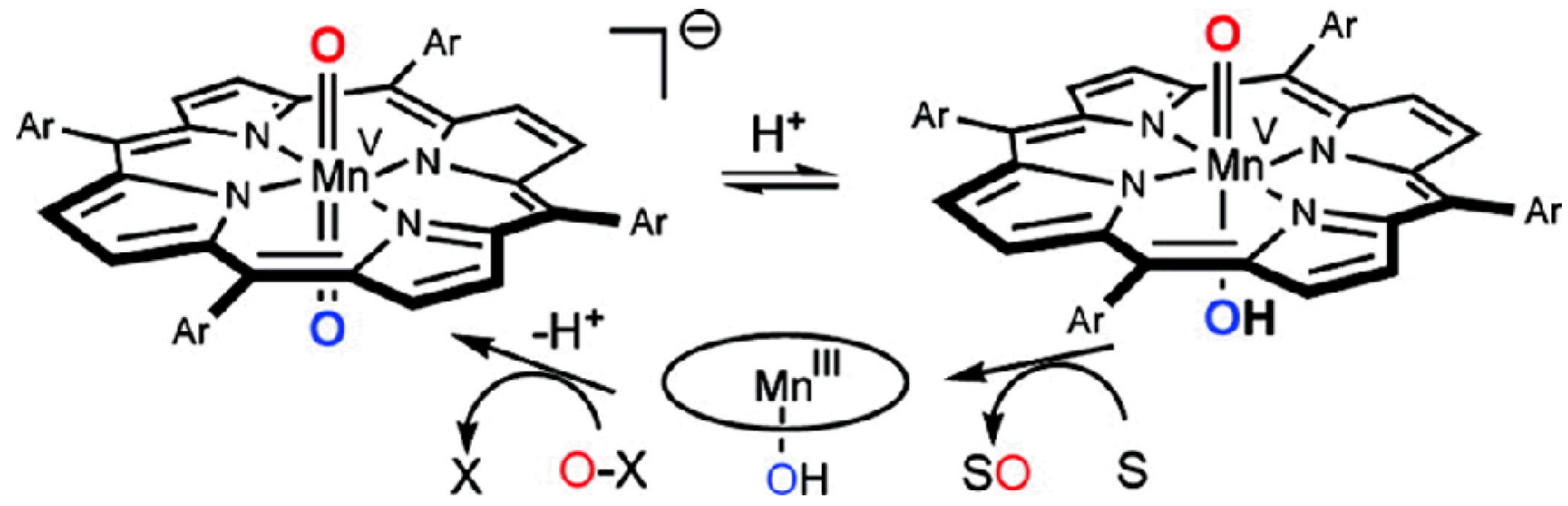

Scheme 1. 


\section{Table 1}

Raman Data for Dioxo Manganese(V) Porphyrins

\begin{tabular}{|l|c|c|c|c|}
\hline $\begin{array}{l}\text { manganese } \\
\text { porphyrins }\end{array}$ & $\mathbf{v}\left({ }^{\mathbf{1 6}} \mathbf{O}\right) / \mathbf{c m}^{-1}$ & $\begin{array}{c}\Delta\left(^{\mathbf{1 6}} \mathbf{O} /{ }^{\mathbf{1}} \mathbf{O}\right) / \mathbf{c m}^{-1} \\
\text { half- } \\
\text { labeled }\end{array}$ & $\begin{array}{c}\text { fully- } \\
\text { labeled }\end{array}$ & meso-substituents \\
\hline MnTDCPP $^{a}$ & 741 & 21 & 39 & 2,6 -dichlorophenyl \\
\hline MnTPFPP $^{a}$ & 743 & 26 & 44 & pentafluorophenyl \\
\hline MnTMP $^{b}$ & 741 & 25 & 44 & $2,4,6$-mesityl \\
\hline MnTDMImP $^{c}$ & 744 & 24 & 40 & $N, N$-dimethyl-imidazolium-2-yl \\
\hline MnTM-2-PyP $^{c}$ & 744 & 26 & 41 & $N$-methyl pyridinium-2-yl \\
\hline
\end{tabular}

$a_{\text {Solvents: }}$ 9:1(v/v) $\mathrm{CH}_{3} \mathrm{CN} / \mathrm{H}_{2} \mathrm{O}, 10 \mathrm{mM}$ TBAH.

${ }^{b}$ Solvents: $\mathrm{CH}_{3} \mathrm{CN}, 10 \mathrm{mM}$ TBAH.

${ }^{c}$ Solvents: $\mathrm{H}_{2} \mathrm{O}, 100 \mathrm{mM} \mathrm{NaOH}$. 